\title{
The Influence of Utilitarian and Hedonic Consumption Values on Consumer Attitude Towards Online Shopping and Purchasing Intentions
}

\author{
E.H. Redda*
}

North-West University, South Africa

\begin{abstract}
Motivation: Online shopping is increasingly becoming a global phenomenon. In marketing literature, utilitarian and hedonic values are well-known consumption values that explain consumer behaviour and consumer decisionmaking. The purpose of this study is to determine the influence of utilitarian and hedonic consumption values on consumer attitude towards online shopping that, in turn, influences online purchasing intentions. In doing so, the study aims to deepen the understanding of consumer behaviour in an online environment, which marketing practitioners may find useful as the phenomenon of online shopping gains momentum in the $4^{\text {th }}$ industrial revolution.

Methodology and Methods: This study followed a descriptive research design, and a quantitative research method. Data (sample, $n=215$ ) was collected using a self-administrated questionnaire from consumers with diverse socio-economic backgrounds through Survey Monkey. The well-known utilitarian and hedonic scales were adapted to suit the online shopping context, and utilised to collect empirical data for the study. Descriptive statistics, correlation analysis and structural equation modelling were applied to address the research objectives, and to test the hypothesised research model.

Data and Empirical Analysis: The study found that four attributes/values, namely wider selection, efficiency, convenience and cost saving are determinants of consumers' utilitarian motivation towards online shopping, while another set of four attributes/values, viz. adventure/explore, gratification, social and idea constituted consumers' hedonic motivation towards online shopping were found. Furthermore, the study found that utilitarian and hedonic motivations are determinants of consumer attitude towards online shopping, while, in turn, consumer attitude was found to be a predictor of online purchasing intentions.

Novelty: The study contributes to the literature on the contemporary online shopping phenomenon. Conducted in an emerging economy (South Africa), it provides a deeper understanding of, and an insight into how consumers behave and make decisions in an online environment.

Policy Consideration: At a practical level, the paper has devised a tool (framework) for marketing practitioners to utilise in influencing consumer attitude towards online shopping and purchasing intentions, and ultimately conclude a sale through online transaction.
\end{abstract}

Keywords: Online shopping, utilitarian motivation, hedonic motivation, consumer behaviour, consumer attitude.

\section{INTRODUCTION}

The internet has become a vital channel for shopping (To, Liao \& Lin, 2007), and businesses are able to target a vast audience regardless of their location (Rosário1 \& Cruz, 2019). Online shopping is increasingly becoming a global phenomenon. This is primarily because the internet has created a unique and convenient platform for consumers around the world to explore, shop and make purchase online anytime from anywhere in the world, and businesses are taking advantage of this technology (Redda, 2019). The digital economy across the world is growing fast and is being used as a source of competitive advantage in international markets (Stroev, Firsov \& Reshetnikov, 2019). Understanding consumer attitude and purchasing intentions in an online environment is crucial for marketing practitioners and researchers

${ }^{*}$ Address correspondence to this author at the North-West University, South Africa; E-mail: Ephrem.Redda@nwu.ac.za, ehredda@gmail.com

JEL Classification: M3; M30; M31. alike. Having sound knowledge of what influences such attitude and purchasing intentions of online shopping is even more crucial.

A record into marketing literature shows that a number of theories and conceptual frameworks have been developed to explain consumer behaviour and consumer decision-making processes. Some of the prominent theories include the "diffusion of innovations" by Rogers (1995), the "theory of reasoned action" by Ajzen and Fishbein (1980), the "theory of planned behaviour" by Ajzen and Madden (1986), the "decomposed version of the theory of planned behaviour" by Taylor and Todd (1995), the "technology acceptance model" by Davis, Bagozzi and Warshaw (1989) and the "extended version of technology acceptance model" by Venkatesh and Davis (2000).

\section{LITERATURE REVIEW}

Central in marketing is the concept of exchange. The concept of exchange, as a paradigm, has proven 
to be a useful framework for explaining and conceptualising marketing behaviour (Bagozzi, 1975:32). In marketing theory, "every exchange is supposed to produce utility, which means the value of what you trade is less than the value of what you receive from the trade" (Thompson, 2019). As the title of this paper suggests, the focus of this paper is on utilitarian and hedonic consumption values. This paper investigates the role of utilitarian and hedonic consumption values in influencing consumer attitude and purchasing intentions of online shopping. In marketing literature, utilitarian and hedonic consumption values are well-known consumption values that explain consumer behaviour and consumer decision-making. Babin and Harris (2016:28) assert that at the heart of the consumer-valueframework(CVF), and the central notion in consumer behaviour, is value which is described as "what consumers ultimately pursue and it captures how much gratification a consumer receives from consumption". Zeithaml (2012) posits that customers define value in four ways: "i) value is low price; ii) value is whatever I want in a product or service; iii) value is the quality I get for the price I pay; and iv) value is what I get what I give". Babin and Harris (2016:28) suggest the following simple equation on how a consumer may determine the overall worth of something for its value:

$$
\text { value }=\text { what you get }- \text { what you give }
$$

Where what you get may include benefits such as "quality, convenience, emotions, prestige, experience and other factors such as scarcity and nostalgia; and what you give may include sacrifices of time, money, effort, opportunity, emotions and image" (Babin \& Harris, 2016:28).

Babin and Harris (2016) argue that while theoretically it is possible to break-down the concept of value into different aspects or classifications, the most useful value typology can be derived using the utilitarian and hedonic value propositions. Briefly explained, utilitarian consumption value refers to the "utility or functional value of an object", whereas hedonic consumption value refers to the "emotional or sensory experiences of online shopping" (Batra \& Ahtola, 1991). The dimensions or attributes of utilitarian consumption values may include achievement, efficiency, value and wider selection (Arnold \& Reynolds, 2003; Kim, 2006; To et al., 2007). Similarly, the dimensions or attributes of hedonic consumption values may include "adventure shopping, gratification shopping, role playing, social interaction, value shopping and idea shopping" (Arnold \& Reynolds, 2003; Kim, 2006; To et al., 2007). Conceptually, there are significant differences between these two value propositions. Firstly, "hedonic value is an end in and of itself rather than a means to an end; secondly, hedonic value is very emotional and subjective in nature; and thirdly, when a consumer does something to obtain a hedonic value, it can be difficult to explain the action objectively" (Babin \& Harris, 2016:28).

\section{Problem Statement}

Having a sound understanding of the dimensions/attributes that constitute utilitarian and hedonic consumption values is critical in our quest to comprehend and explain consumer behaviour and consumer decision-making. An avalanche of studies has been conducted that determine the effect of utilitarian and hedonic consumption values on customer satisfaction, attitude and purchasing intentions on the goods market and service industries (Babin, Darden \& Griffin, 1994; Arnold \& Reynolds, 2003; Kim, 2006; Guido, 2006). Only few have focused on the context of online shopping (To et al., 2007; Moon, et al., 2017). A study by To et al. (2007) found that utilitarian motivation is an antecedent of consumer intention to search and intention to purchase over the Internet. Importantly, the study found that hedonic consumption value has a direct effect on consumer intention to search, and indirect effect on purchasing intentions. Another interesting finding of this study is that utilitarian consumption value is the stronger predictor of consumer intention to search, and intention to purchase compared to hedonic consumption value. The study did not attempt to determine the influence of these motivations (both utilitarian and hedonic motivations) on consumer attitude towards online shopping with the present study aim to do. Another study that attempted to address a similar issue is that of Moon et al. (2017), which studied consumers' perception of websites' utilitarian and hedonic attributes and purchasing intentions. The study found that "consumers' perception of utilitarian attributes and hedonic attributes are significant and positive predictors of cognitive and affective attitude". Furthermore, that study found that "cognitive and affective attitudes are significant and positive predictors of consumers' purchase intentions" in an online environment. Within the South African context, research in the areas of attitude towards online shopping and purchasing intentions based on utilitarian and hedonic consumption values remains unexplored. In light of the apparent limitation of empirical research, 
the present study attempts to fill the void by examining the influence of utilitarian and hedonic consumption values on consumer attitude towards online shopping and purchasing intentions.

\section{CONCEPTUAL FRAMEWORK, AND HYPOTHESIS FORMULATION}

This section elucidates the conceptual framework and hypotheses formulation based on the two broad typologies of consumption values, namely utilitarian and hedonic consumption values. The research model tested in this study is depicted in Figure 1.

\section{Utilitarian Consumption Values}

Utilitarian values/attributes are "directed toward achieving goals, and they relate to efficiency and rational decision-making; they refer to the utility or functional value of an object" (Batra \& Ahtola, 1991). The concept of utilitarian value refers to the "gratification derived from something that enables the consumer to solve problems or accomplish tasks" (Babin \& Harris, 2016: 29). Within this context, the purchase of the physical product or service is meant to accomplish a certain task. Put differently, it is meant to satisfy a functional or economic need, and the shopping is compared to a task and the value accrued is weighed on the success or completion of the task (Hirschman \& Holbrook, 1982). Various attributes/values have been cited as determinants of utilitarian consumption values within online and offline/traditional business contexts.

To et al. (2017) empirically tested six utilitarian values that motivated consumers to do online search and purchase intentions; these values included cost saving, convenience, selection, information availability, lack of sociality and customisation. Likewise, Moon et al. (2017) applied four attributes, namely product information, monetary saving, convenience and ease of use to determine online purchase intentions.

As elucidate above, various empirical studies have been undertaken that attempted to establish the attributes that create utilitarian values for consumers be it in online or offline settings. In the immediate section below, focus is placed on what constitutes and influences consumers' utilitarian consumption values within the context of online shopping. Based on the literature study and the efficacy of their findings, the utilitarian consumption values tested in this study comprise:
- Wider/diversified selection;

- Information availability;

- $\quad$ Efficiency;

- Achievement;

- Convenience and

- $\quad$ Cost saving/better deals.

Wider/diversified selection is often described as the primary motivation for consumers to engage in online shopping (Alba et al. 1997; Arnold \& Reynolds, 2003; Kim, 2006; To et al., 2007). With online shopping, consumers are spoiled with a wider selection of products over the internet (Delafrooz et al., 2009). Information availability regarding product specifications, prices and promotions also plays a crucial role in enticing consumers into buying products through the online channel (Wolfinbarger \& Gilly, 2001). The ease with which consumers can search for products that satisfy their need and conclude the transaction over the internet is appealing to consumers. As a result, consumers are able to get (achieve) what they need efficiently through online is an important value proposition to consumers (utilitarian value). The term efficiency in this case refers to the "consumer needs to save time and resources, while achievement refers to a goal-related shopping orientation where success in finding specific products that were planned for at the outset of the trip is important" (Babin et al., 1994; Kim, 2006). Obtaining (and perhaps buying) what consumers need is an important driver of utilitarian consumption values in online shopping. A closely related concept that results in creating utilitarian value is the convenience that online shopping offers to consumers; a convenience that is not bound by time, space or weather (Burke, 1997). Travelling and waiting in lines are avoided. Consumers are able to conduct their shopping 24 hours a day conveniently from the comfort of their homes (Redda, 2018). Cost saving/better deals is also an added advantage that contributes value to consumer when they purchase through online; consumers are able to negotiate better deals and get products at lower prices (To et al., 2007). This is because businesses that sell online are able to save money on rent and personnel of a typical brick and mortar store.

In line with the theoretical and empirical foundations implicated above, the following alternative hypotheses are formulated (also see Figure $\mathbf{1}$ for graphical illustration): 
$H_{1}$ : Diversified/wider selection has a significant positive influence on utilitarian motivation for online shopping.

$\mathrm{H}_{2}$ : Information availability has a significant positive influence on utilitarian motivation for online shopping.

$H_{3}$ : Efficiency has a significant positive influence on utilitarian motivation on online shopping.

$\mathrm{H}_{4}$ : Achievement has a significant positive influence on utilitarian motivation for online shopping.

$H_{5}$ : Convenience has a significant positive influence on utilitarian motivation for online shopping.

$H_{6}$ : Cost saving/better deals have a significant positive influence on utilitarian motivation for online shopping.

As explicated in the hypotheses formulation, a number of consumption values, namely wider/diversified selection, information availability, efficiency, achievement, convenience and cost saving/better deals are the main contributors to consumers' utilitarian motivation towards online shopping. The utilitarian motivation for online shopping, in this respect, refers to the attributes that the online shopping is seen as an option/channel through which consumers are afforded wider selection of products, with easily available information to conduct purchase (achieve what they want) efficiently with convenience at a reduced cost of purchase. Previous empirical studies in other parts of the world (Childers, Carr, Peck \& Carson, 2002; Chiu \& Ting, 2011) have suggested that utilitarian motivations can significantly influence consumer attitude towards online shopping. Similarly, Moon et al. (2017) found that utilitarian attributes have a positive and significant relationship with cognitive and affective attitude towards online purchase intentions. In keeping with the established literature, it is therefore postulated that if a consumer is said to have attained a utilitarian consumption value (which translates into utilitarian motivation), it will inevitably have a significant positive influence on his/her attitude towards online shopping. Consequently, the following hypothesis is formulated:

$H_{7}$ : Utilitarian motivation has a significant positive influence on consumer attitude towards online shopping.

\section{Hedonic Consumption Values}

Hedonic consumption values are defined as the "attributes that deal with the experiences of sensory appeals, which include emotion and gratification" (Batra \& Ahtola, 1991). Therefore, emotional or sensory experiences of shopping are the driving forces of hedonic consumption value. Hedonic consumption value is often referred to as the immediate gratification that comes from experiencing certain activity (Babin \& Harris, 2016:29). The hedonic aspect of shopping has been described as "excitement, arousal, joy, festive, escapism, fantasy and adventure" (Fischer \& Arnold, 1990). Within this context, value is not sought from the actual purchase of the physical product or service, but from the experience and emotions associated with such a purchase. The end result is satisfying emotions and fantasies (Assael, 2004). Hedonic shoppers are "less motivated by the physical usefulness of the product" (Evans et al., 2009); they are motivated by the shopping experience itself (Hoyer, Maclnnis \& Pieters, 2013). Through an empirical study, Arnold and Reynolds (2003) identified six categories that motivate shopping, namely, "adventure, social, gratification, idea, role playing and value shopping". To et al. (2007) tested five hedonic values, viz. adventure/explore, social, idea, value, and authority and status that motivated consumers to do online search and purchase intentions. Similarly, Moon et al. (2017) used three proxies of hedonic attributes in their studies, namely role shopping, best deal and social in their cognitiveaffective attribute approach to determine online purchase intentions.

Up on examination of the empirical studies and the efficacy of their findings, the hedonic consumption values tested in this study include:

- Adventure/explore;

- $\quad$ Gratification shopping;

- Social;

- Idea;

- $\quad$ Authority \& status.

Adventure/explore shopping is a "type of shopping consumer engages for stimulation, adventure, and the feeling of being in another world; the shopping trip is made for the sheer excitement and adventure" (Arnold \& Reynolds, 2003). Kim (2006) concurs and adds stimulation as an important component of adventure shopping. There is a sense of curiosity in consumers that generate the action of adventure shopping (To et al., 2007). Gratification shopping refers when shopping is conducted for purposes of stress relief, alleviate a 
negative mood and as a treatment of oneself (Arnold \& Reynolds, 2003; Kim, 2006). Idea shopping is primarily made to keep up with trends, fashions, innovations (Arnold \& Reynolds, 2003). There is no doubt that the internet can provide such information to consumers to keep the abreast of new products and innovations in the market. Consumers are able to get information about brands, products, and new trends and receive pleasure in the process (To et al., 2007). Social shopping in traditional setting refers to the "enjoyment of shopping with family and friends, socialising while shopping and bonding with others while shopping" (Arnold \& Reynolds, 2003; Kim, 2006; Chiu, Wang, Fang, \& Huang, 2014).). The advent of the internet has created a virtual community (Wolfingarger \& Gilly, 2001) where consumers could share information and shopping experiences with those who have similar interests through online means (To et al., 2007). Authority and status - the internet does provide special authority and status to online shoppers. Online shoppers have the control on what product to see, when to place an order and when to receive the product (Parsons, 2002). The control over technology does provide to online shoppers this authority and status (To et al., 2007).

In accordance with the theoretical and empirical foundations furnished above, the following alternative hypotheses are formulated (also see Figure $\mathbf{1}$ for graphical illustration):

$H_{8}$ : Adventure/explore has a significant positive influence on hedonic motivation for online shopping.

$H_{9}$ : Gratification shopping has a significant positive influence on hedonic motivation for online shopping.

$H_{10}$ : Idea has a significant positive influence on hedonic motivation for online shopping.

$H_{11}$ : Social has a significant positive influence on hedonic motivation for online shopping.

$H_{12}$ : Authority and status have a significant positive influence on hedonic motivation for online shopping.

As elucidated in the process of hypotheses formulation, adventure/explore, gratification, social, idea and authority and status have been identified as the main contributors to consumers' hedonic motivation towards online shopping. The hedonic motivation for online shopping, in this respect, is described the extent to which online shopping is perceived to be fun, exciting, delightful, thrilling and enjoyable. Searches into empirical studies (Childers et al., 2001; Chiu \& Ting, 2011) reveal that hedonic motivations do have a positive impact towards online shopping. Hedonic motivation is also found to specifically influence cognitive affective attitude towards online purchase intentions (Moon et al., 2017). In light of these narratives, it is deemed appropriate to state that:

$H_{13}$ : Hedonic motivation has a significant positive influence on consumer attitude towards online shopping.

The section below focuses on the last component of the research model; the influence of consumer attitude on online purchasing intentions.

\section{Consumer Attitude and Purchasing Intentions}

The relationship between consumer attitude and purchasing intention is a well-documented phenomenon in offline and online businesses. Attitude refers to the "degree to which an individual person may have a favourable or unfavourable evaluation of the behaviour of interest" (Azjen \& Fishein, 1980). Behavioural intentions (in this case purchasing intentions) are motivational factors that influence an individual's behaviour to act, i.e. to do the purchase. The theory postulates that "the stronger the intention of doing a certain task, the more likely the task will be performed" (Ajzen, 1985). Within an online context, George (2004) found that consumer attitude and perceived behavioural control to be predictors of online purchasing. Applying the theory of planned behaviour, Redda (2019) found that consumer attitude toward online shopping does in deed influence shopping behaviour. In line with the foregoing discussion, the following hypothesis is formulated:

$H_{14}$ : Consumer attitude has significant positive influence on online purchasing intentions.

\section{Research Model}

The purpose of this study is to determine the influence of hedonic and utilitarian values on consumers' attitude towards online shopping that, in turn, influences purchasing intentions. The conceptual framework underpinning this study and the hypothesised research model are illustrated Figure 1.

\section{RESEARCH METHOD}

This study implemented descriptive research design, and quantitative research method to address 


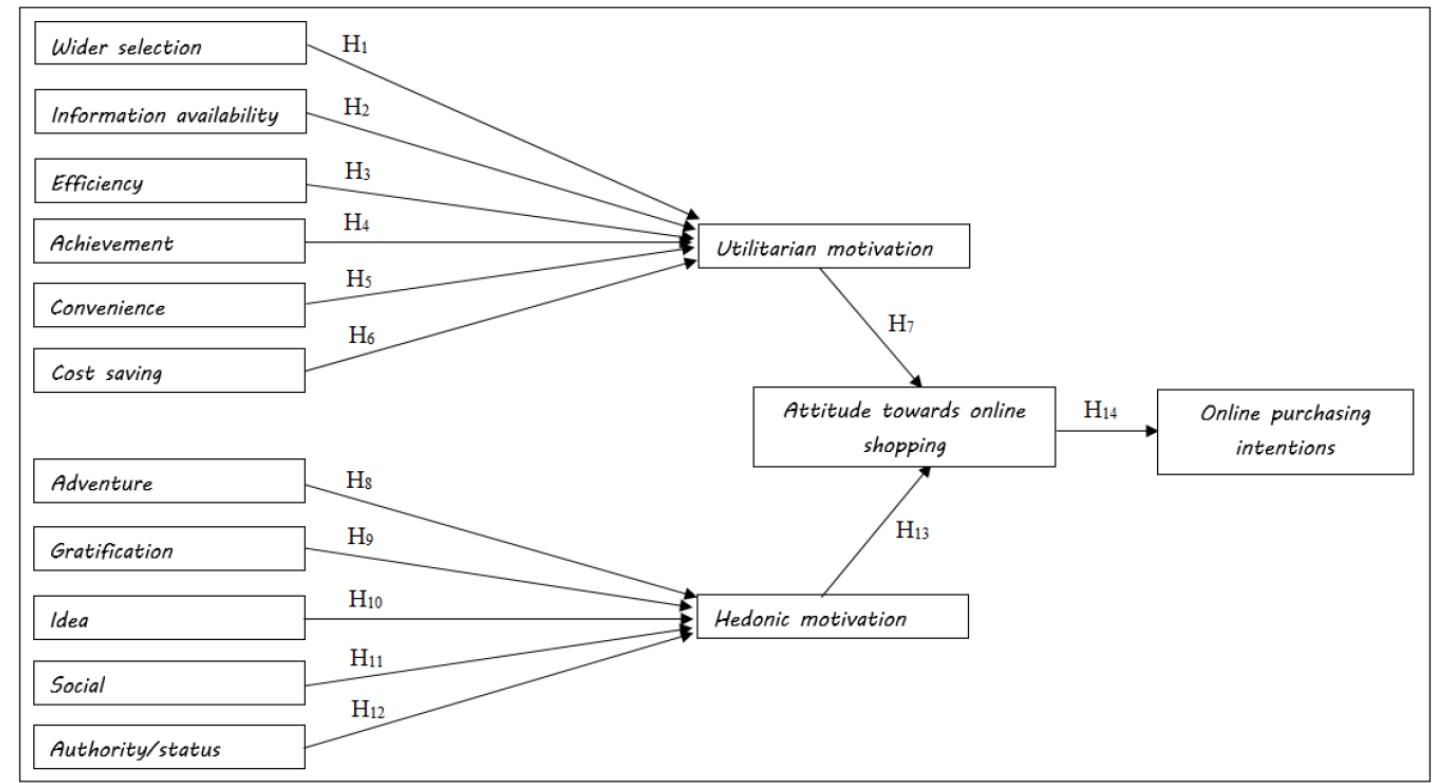

Figure 1: Research model.

the research objectives, and to test the hypothesised research model.

\section{Sampling and Data Collection}

The population of the study included South African consumers who engage in online shopping. Due to the absence of a sampling frame for this population group, probability sampling could not have implemented. Instead, the researcher implemented convenience and snowball sampling techniques, which are examples of non-probability sampling techniques. A structured selfadministered questionnaire was distributed through Survey Monkey to collect data from a diverse group of online shoppers in Gauteng, the economic hub of South Africa in 2018. Using this data collection method, 215 usable responses were obtained and analysed. This sample size is sufficiently large enough to conduct the type of statistics implemented in this study (Malhotra, 2010:377).

\section{Research Instrument}

As explicated above, this paper aims to examine the influence of utilitarian and hedonic consumption values on consumer attitude towards online shopping and purchasing intentions. As well-known consumption values that explain consumer attitude and consumer decision-making, this study has benefited from previously conducted conceptual and empirical research studies. The scales utilised in this study were assessed in terms of their psychometric properties to ensure the reliabilities of the measurement items.
The variables and measurement items for the utilitarian and hedonic values used in this research instrument were drawn from validated scales of priori research (Arnold \& Reynolds, 2003; Kim, 2006; To et al., 2007). For utilitarian values: wider/diversified selection (three items), information availability (three items), efficiency (three items), achievement (three items), convenience (four items) and cost saving/better deals (three items) were compiled. Similarly, for hedonic values: adventure/explore (three items), gratification (three items), social (three items), idea (three items) and authority and status (three items) were compiled. The measurement items for attitude (four items) and purchasing intentions (four items) were adapted from the theory of planned behaviour (TPB) (Azjen, 1985, 1991). A six-point Likert scale (anchored from 1 (strongly disagree) to 6 (strongly agree)) was used to capture responses. A pilot study (with a sample of 50) was conducted in order to ascertain the internalconsistency reliability of the scale as an additional measure before collecting data for the main study. A Cronbach alpha greater than 0.70 was obtained for all the constructs, and therefore no items were removed during the pilot testing stage.

\section{Ethical Considerations}

The instrument used to collect data classified as low risk and, necessary ethical clearance (ECONIT-2017088) was obtained from the North-West University. All responses are reported in aggregate and participation in the study was on a voluntary basis. 


\section{Data Analysis}

The collected data was analysed using SPSS with Amos version 25 Microsoft Windows.

\section{EMPIRICAL FINDINGS AND DISCUSSION}

\section{Sample Description}

As illustrated in Table 1, the sample of 215 was balanced in terms of gender; $55.35 \%(n=119)$ were female and $44.65 \% \quad(n=96)$ were male. The demographic data revealed that the majority of the respondents were between 35 and 44 years of age $(25 \%)$, followed by age cohort 18 to $24(33 \%)$ and age cohort 25 to $34(13 \%)$. Only 11 percent were above the age of 45 . Majority (above $80 \%$ ) of the respondents indicated that they shop online for fashions, branded products and overseas products (products not available in local markets). A significant number $(65 \%)$ of the respondents indicated they shop online for local products and athletic products.

\section{Reliability and Validity Analysis}

In order to determine the internal-consistency and reliability of the scales used during data collection, the Cronbach's alpha $(\alpha)$ was computed for all the scaled items of the questionnaire (Beckstead, 2013). The results presented in Table 2 suggest that the Cronbach alpha coefficients for all the scaled variables were above 0.70 threshold, proving acceptable level internalconsistency reliability (Hair, Black, Babin \& Anderson, 2010). As shown on Table 2, the average/mean interitem correlation (MIIC) for all the variables ranged between 0.15 and 0.50 , which is indicative of convergent and discriminant validity of the instrument utilised (Clark \& Watson, 1995). Furthermore, the standardised loading estimates of the items of the variables were above the 0.50 mark providing further evidence of convergent validity (Hail et al., 2010). Additional two measures viz. composite reliability (CR) and average variance extracted (AVE) produced values in excess of 0.70 and 0.50 , respectively showing further support of convergent validity. The values of average variance extracted (AVE) are shown on a diagonal line, highlighted in bold font in Table 2.

\section{Correlation Analysis and Multicollinearity Concerns}

As shown in Table 2, it is evident that there were statistically significant $(p \leq 0.05)$ linear associations/relationships between each pair of the variables tested in the model. This provided evidence for nomological validity (Malhotra, 2010). All the correlation coefficients were below the 0.90 mark providing evidence that there was no obvious multicollinearity concern between the variables tested in the model (Hair et al., 2010). Additional collinearity diagnostics were computed to ensure that multicollinearity concern is not present between the variables. Each of the variables tested in the model produced a tolerance values above the 0.10 threshold level, and the variance inflation factor (VIF) below the cut-off of 10 , providing support for the absence of multicollinearity between the variables (Pallant, 2013).

\section{Measurement Model}

SEM is "a second-generation multivariate analysis technique that is used to determine the extent to which a priori theoretical model is supported by the sample data" (Schumacker \& Lomax, 2010). In this study, the researcher's aim was to examine the influence of utilitarian and hedonic consumption values on consumer attitude towards online shopping and purchasing intentions as depicted in Figure 1. As a standard procedure, "the measurement model was first

Table 1: Descriptive Statistics

\begin{tabular}{|c|c|c|c|}
\hline Age & $\%$ & Products & $\%$ \\
\hline \hline $18-24$ & 23 & Fashions & 93.00 \\
\hline $25-34$ & 41 & Oversea products & 85.00 \\
\hline $35-44$ & 25 & Branded products & 60.00 \\
\hline Above 45 & 11 & Athletic products & 65.00 \\
\hline Gender & & Local products & 45.00 \\
\hline Male & 53 & Books & 37.00 \\
\hline Female & 47 & Other & 20.00 \\
\hline
\end{tabular}


Table 2: Correlation Statistics, Validity and Reliability Statistics

\begin{tabular}{|c|c|c|c|c|c|c|c|c|c|c|c|c|c|c|c|c|c|c|c|}
\hline Variables & & $a$ & CR & MIIC & F1 & F2 & F3 & F4 & F5 & F6 & F7 & F8 & F9 & F10 & F11 & F12 & F13 & F14 & F15 \\
\hline Wider selection & (F1) & 0.75 & 0.71 & 0.23 & 0.69 & & & & & & & & & & & & & & \\
\hline Information & (F2) & 0.81 & 0.75 & 0.33 & 0.41 & 0.66 & & & & & & & & & & & & & \\
\hline Efficiency & (F3) & 0.79 & 0.72 & 0.19 & 0.55 & 0.45 & 0.61 & & & & & & & & & & & & \\
\hline Achievement & (F4) & 0.79 & 0.72 & 0.28 & 0.43 & 0.55 & 0.45 & 0.65 & & & & & & & & & & & \\
\hline Convenience & (F5) & 0.80 & 0.75 & 0.23 & 0.42 & 0.45 & 0.45 & 0.37 & 0.59 & & & & & & & & & & \\
\hline Cost saving & $(\mathrm{F} 6)$ & 0.83 & 0.76 & 0.23 & 0.50 & 0.35 & 0.36 & 0.37 & 0.41 & 0.53 & & & & & & & & & \\
\hline Adventure/explore & (F7) & 0.87 & 0.79 & 0.28 & 0.49 & 0.45 & 0.39 & 0.45 & 0.45 & 0.43 & 0.54 & & & & & & & & \\
\hline Gratification & (F8) & 0.78 & 0.70 & 0.37 & 0.55 & 0.39 & 0.45 & 0.35 & 0.36 & 0.44 & 0.56 & 0.63 & & & & & & & \\
\hline Social & (F9) & 0.86 & 0.75 & 0.38 & 0.43 & 0.31 & 0.38 & 0.45 & 0.39 & 0.40 & 0.50 & 0.47 & 0.58 & & & & & & \\
\hline Idea & (F10) & 0.87 & 0.75 & 0.27 & 0.40 & 0.35 & 0.44 & 0.60 & 0.55 & 0.45 & 0.58 & 0.60 & 0.39 & 0.66 & & & & & \\
\hline Authority \& status & (F11) & 0.85 & 0.74 & 0.29 & 0.39 & 0.40 & 0.39 & 0.45 & 0.35 & 0.38 & 0.35 & 0.36 & 0.45 & 0.45 & 0.51 & & & & \\
\hline Utilitarian & (F12) & 0.83 & 0.74 & 0.29 & 0.31 & 0.39 & 0.36 & 0.38 & 0.46 & 0.36 & 0.45 & 0.39 & 0.45 & 0.40 & 0.55 & 0.65 & & & \\
\hline Hedonic & (F13) & 0.78 & 0.73 & 0.22 & 0.35 & 0.35 & 0.45 & 0.45 & 0.35 & 0.44 & 0.38 & 0.31 & 0.38 & 0.50 & 0.50 & 0.65 & 0.63 & & \\
\hline Attitude & (F14) & 0.79 & 0.73 & 0.18 & 0.45 & 0.40 & 0.38 & 0.38 & 0.45 & 0.45 & 0.40 & 0.42 & 0.39 & 0.45 & 0.45 & 0.45 & 0.44 & 0.58 & \\
\hline Intentions & (F15) & 0.79 & 0.72 & 0.41 & 0.41 & 0.41 & 0.45 & 0.54 & 0.31 & 0.38 & 0.39 & 0.37 & 0.36 & 0.37 & 0.47 & 0.41 & 0.33 & 0.55 & 0.67 \\
\hline
\end{tabular}

specified and identified, and the measured indicator items were assigned to the latent variables of the model" (Malhotra, 2010; Hair et al., 2010). Following this, a confirmatory factor analysis (CFA) was conducted. The CFA model comprised fourteen (14) latent and manifest variables, namely utilitarian motivation, wider selection, information availability, efficiency, achievement, convenience, cost saving, hedonic motivation, adventure/explore, gratification shopping, social, idea, authority/status, attitude and purchase intentions. All items scored factor loadings above the minimum acceptable threshold of 0.50 ; items below the 0.50 threshold were not considered for analysis.

\section{Model Fit Assessment}

The most commonly used indices including goodness-of-fit index (GFI), adjusted goodness-of-fit index (AGFI), incremental fit index (IFI), Tucker Lewis index (TLI) and comparative fit index (CFI) were calculated to assess the goodness-of-fit of the structural model. It is suggested that "Index values closer to one (1) are said to represent a perfect fit of the model, while index values closer to zero (0) are believed to represent no fit at all" (Malhotra, 2010; Hair et al., 2010). As a standard procedure two competing models were considered as illustrated in Table $\mathbf{3}$. The figures presented in the table below (Table 2) suggest that on balance structural model 2 portrayed a better model fit for the dataset.

\section{Utilitarian and Hedonic Motivations of Online Shopping}

The empirical results presented in Figure 2 illustrate the path coefficients and the squared multiple correlation (SMC) between the various variables tested in the structural model. The results regarding the decisions of the hypotheses are presented in Table 4.

\section{Utilitarian Values that Constitute Utilitarian Motivation}

Of the six value attributes that were proposed as determinants of utilitarian motivation towards online

Table 3: Structural Model Fit Assessment

\begin{tabular}{|c|c|c|c|c|c|c|c|c|}
\hline \multicolumn{4}{|c|}{} & \multicolumn{3}{c|}{ Absolute fit indices } & \multicolumn{3}{c|}{ Incremental fit indices } \\
\hline Model fit indices & $\lambda^{2} /$ df & GFI & AGFI & RMSEA & NFI & TLI & CFI & IFI \\
\hline \hline Model 1 & 4.666 & 0.878 & 0.898 & 0.087 & 0.892 & 0.954 & 0.934 & 0.900 \\
\hline Model 2 & 2.536 & 0.953 & 0.930 & 0.038 & 0.940 & 0.960 & 0.988 & 0.949 \\
\hline Acceptable value & $<3.00$ & $>0.90$ & $>0.80$ & $<0.08$ & $>0.90$ & $>0.90$ & $>0.90$ & $>0.90$ \\
\hline
\end{tabular}

Source: Hair et al. (2010); Malhotra (2010). 


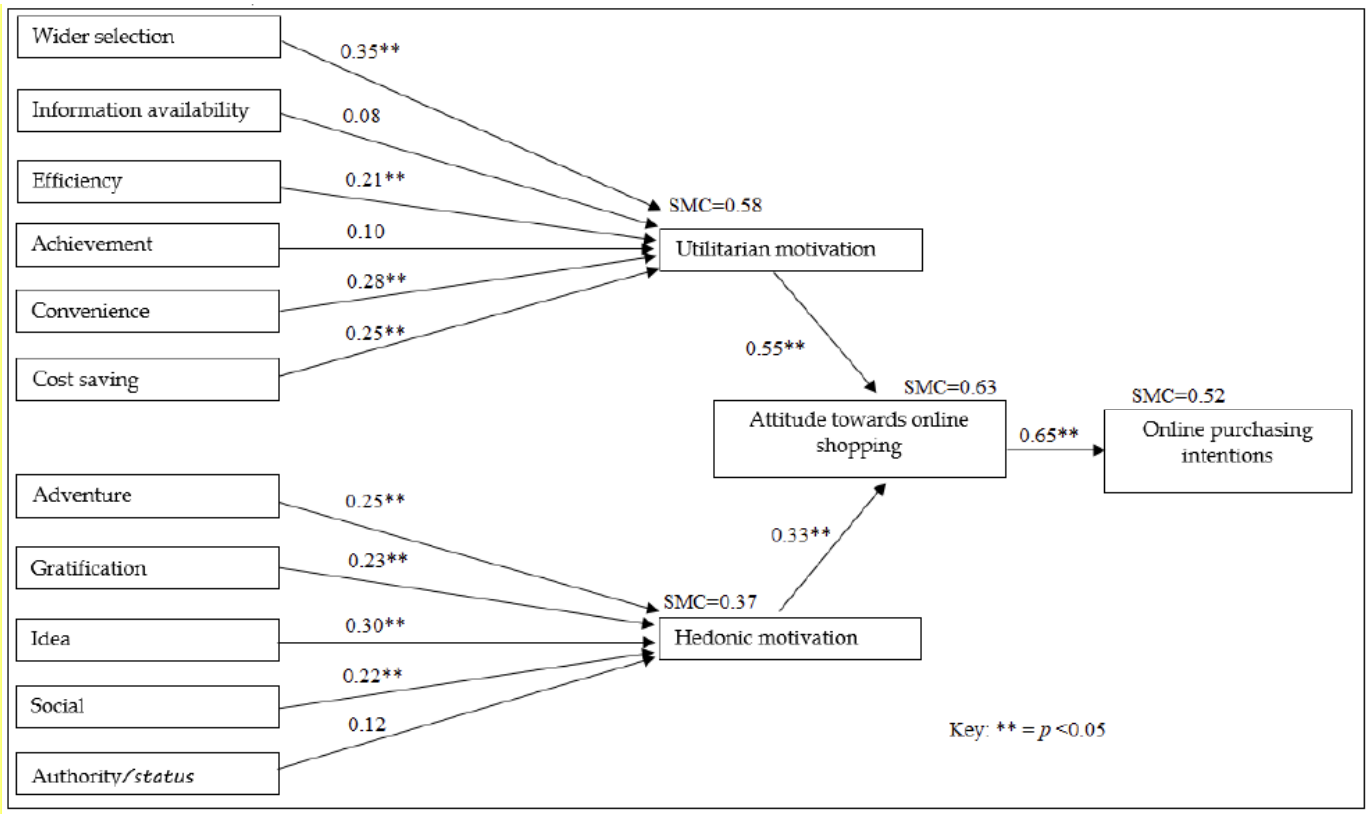

Figure 2: Empirical findings.

shopping, only four viz. wider selections $(\beta=0.35 ; p<$ $0.01)$, efficiency $(\beta=0.21 ; p<0.05)$, convenience $(\beta=$ $0.28 ; p<0.05)$ and cost saving $(\beta=0.25 ; p<0.05)$ were found to have statistically significant influence. Information availability and achievement were not found to have statistically significant contribution to utilitarian motivation. Collectively, these attributes/values with statistical significance produced an SMC of 0.58 , which signifies that approximately 58 percent of the variance on consumer utilitarian motivation is explained by these utilitarian values. Subsequently, $\mathrm{H}_{1}, \mathrm{H}_{3}, \mathrm{H}_{5}$ and $\mathrm{H}_{6}$ are supported while no support is provided for $\mathrm{H}_{2}$ and $\mathrm{H}_{4}$.

\section{Utilitarian Motivation on Consumer Attitude Towards Online Shopping}

$\mathrm{H}_{7}$ proposed that utilitarian motivation has significant positive influence on consumer attitude towards online shopping. The results of the study as reported in Figure $\mathbf{2}$ and Table $\mathbf{4}$ indicate that there is a statistically significant relationship $(\beta=0.55 ; p<0.01)$; $\mathrm{H}_{7}$ is supported. This finding is in congruence with theory and other empirical studies (Childers, Carr, Peck \& Carson, 2002; Chiu \& Ting, 2011; Moon et al., 2017).

\section{Hedonic Values that Constitute Hedonic Motivation}

Initially, the study proposed that five hedonic values/attributes constitute hedonic motivation towards online shopping. Of these five values/attributes, only four, namely adventure/explore shopping $(\beta=0.25$; $p<$ $0.05)$, gratification shopping $(\beta=0.23 ; p<0.05)$, social shopping $(\beta=0.22 ; p<0.05)$ and idea shopping $(\beta=$ $0.30 ; p<0.01$ ) were found to have statistically significant influence. The authority and status construct was not found to have statistically significant contribution to hedonic motivation. These attributes/values with statistical significance collectively produced an SMC of 0.37 , which signifies that approximately 37 percent of the variance on consumer hedonic motivation is explained by these hedonic values/attributes. Subsequently, $\mathrm{H}_{1}, \mathrm{H}_{2}, \mathrm{H}_{3}$ and $\mathrm{H}_{4}$ are supported, while no support is provided for $\mathrm{H}_{12}$.

\section{Hedonic Motivation on Consumer Attitude Towards Online Shopping}

$\mathrm{H}_{13}$ proposed that hedonic motivation has significant positive influence on consumer attitude towards online shopping. The results of the study as illustrated in Figure 2 indicate that there is a statistically significant relationship ( $\beta=0.33 ; p<0.05$ ). Therefore, $\mathrm{H}_{13}$ is supported. This finding is in line with theory and other empirical studies (Childers et al., 2001; Chiu \& Ting, 2011; Moon et al., 2017).

\section{Consumer Attitude on Online Purchasing Intentions}

As elucidated above, utilitarian motivation $\left(\mathrm{H}_{7}\right)$ as well as hedonic motivation $\left(\mathrm{H}_{13}\right)$ were found to have a statistically significant influence on consumer attitude towards online shopping. The SMC of 0.63 suggests that approximately 63 percent of the variance on consumer attitude towards online shopping is explained 
Table 4: Hypotheses Results

\begin{tabular}{|c|c|c|c|c|c|}
\hline Variables & SMC & Path coeff. & T-value & $p$-values & Results of hypothesis \\
\hline $\mathrm{H}_{1}$ : Wider selection to utilitarian motivation & \multirow[t]{6}{*}{0.58} & 0.35 & 5.10 & 0.00 & Supported \\
\hline $\mathrm{H}_{2}$ : Information availability to utilitarian motivation & & 0.08 & 1.20 & 0.15 & Not supported \\
\hline $\mathrm{H}_{3}$ : Efficiency to utilitarian motivation & & 0.21 & 2.45 & 0.01 & Supported \\
\hline $\mathrm{H}_{4}$ : Achievement to utilitarian motivation & & 0.10 & 1.35 & 0.13 & Not supported \\
\hline $\mathrm{H}_{5}$ : Convenience to utilitarian motivation & & 0.28 & 3.20 & 0.01 & Supported \\
\hline $\mathrm{H}_{6}$ : Cost saving/better deals to utilitarian motivation & & 0.25 & 2.90 & 0.01 & Supported \\
\hline $\mathrm{H}_{8}:$ Adventure/explore to hedonic motivation & \multirow[t]{5}{*}{0.37} & 0.25 & 2.93 & 0.01 & Supported \\
\hline $\mathrm{H}_{9}$ : Gratification shopping to hedonic motivation & & 0.23 & 2.50 & 0.01 & Supported \\
\hline $\mathrm{H}_{10}$ : Idea to hedonic motivation & & 0.30 & 4.90 & 0.00 & Supported \\
\hline $\mathrm{H}_{11}$ : Social to hedonic motivation & & 0.22 & 2.49 & 0.01 & Supported \\
\hline $\mathrm{H}_{12}:$ Authority \& status to hedonic motivation & & 0.12 & 1.31 & 0.12 & Not supported \\
\hline $\mathrm{H}_{7}$ : Utilitarian motivation to attitude & \multirow[t]{2}{*}{0.63} & 0.55 & 5.97 & 0.00 & Supported \\
\hline $\mathrm{H}_{13}$ : Hedonic motivation to attitude & & 0.33 & 5.23 & 0.00 & Supported \\
\hline $\mathrm{H}_{14}$ : Attitude to online purchase intention & 0.52 & 0.65 & 6.37 & 0.00 & Supported \\
\hline
\end{tabular}

by these two motivations. By comparison, utilitarian motivation ( $\beta=0.55 ; p<0.01$ ) was found to be a stronger predictor of consumer attitude towards online shopping than does hedonic motivation $(\beta=0.33 ; p<$ 0.01 ).

$\mathrm{H}_{14}$ proposed that consumer attitude has a significant positive influence on online purchasing intentions. In keeping with theory and previously conducted studies (Azjen \& Fishein, 1980; Moon et al., 2017), the results reported in Figure 2 provide evidence of a positive and significant relationship $(\beta=0.65 ; p<$ $0.01)$. Consequently, the hypothesis $\left(\mathrm{H}_{14}\right)$ is supported. The SMC $=0.52$ signifies that approximately 52 percent of the variance on consumer online purchasing intentions is explained by online consumer attitude, which, in turn, is influenced by utilitarian and hedonic motivations.

\section{CONCLUSION AND RECOMMENDATIONS}

The ultimate challenge for any marketing practitioner is to conclude a sale, be it in an online or offline setting. Influencing consumer attitude and purchasing intentions is a step closer to this ultimate challenge. By determining the influence of utilitarian and hedonic consumption values on consumer attitude towards online shopping and purchasing intentions, this paper has provided a deeper understanding, and an insight on how consumers behave and make decisions in an online environment.

The study has found that four attributes/values, namely by wider selection, efficiency, convenience and cost saving as determinants of consumers' utilitarian motivation towards online shopping, while another set of four attributes/values, namely adventure/explore, gratification, social and idea constituted consumers' hedonic motivation towards online shopping. Furthermore, the study found that both utilitarian and hedonic motivations are determinants of consumer attitude towards online shopping. However, utilitarian motivation was found to be a stronger predictor of consumer attitude towards online shopping than hedonic motivation was. In turn, consumer attitude was found to be a predictor of online purchasing intentions.

At a practical level, the paper has devised a tool for marketing practitioners to utilise in influencing consumer attitude towards online shopping and purchasing intentions, and ultimately conclude a sale through online transaction. Various marketing techniques can be applied with respect to the various variables of utilitarian and hedonic consumption values to influence online consumption behaviour and purchasing decisions. A self-report bias can be regarded as a limitation as study relied on selfadministered questionnaires to collect data. Future studies may consider testing other theories to explain 
consumer motivations on online shopping attitude and purchasing intentions.

\section{REFERENCES}

Ajzen, I. \& Fishbein, M. (1980). Understanding Attitudes and Predicting Social Behavior. Prentice-Hall, Englewood Cliffs, NJ.

Ajzen, I. \& Madden, T.J. (1986). Prediction of goal-directed behavior: Attitudes, intentions, and perceived behavioral control. Journal of Experimental Social Psychology, 22(5), pp. 453474 https://doi.org/10.1016/0022-1031(86)90045-4

Ajzen, I. (1985). From intentions to actions: a theory of planned behavior", in Kuhl, J. and Beckman, J. (Eds), Action Control: From Cognition to Behavior, Springer, Heidelberg, pp. 11-39. https://doi.org/10.1007/978-3-642-69746-3_2

Ajzen, I. (1991). The theory of planned behavior. Organizational Behavior and Human Decision Processes, 50, 179-211. https://doi.org/10.1016/0749-5978(91)90020-T

Alba, J., Lynch, J., Weitz, B., Janiszewski, C., Lutz, R., Sawyer, A. \& Wood, S. (1997). Interactive home shopping: consumer, retailer, and manufacture incentives to participate in electronic marketplaces. Journal of Marketing 61(3), 38-53. https://doi.org/10.1177/002224299706100303

Arnold, M. J. \& Reynolds, K. E. (2003). Hedonic shopping motivations. Journal of Retailing, 79, 77-95. https://doi.org/10.1016/S0022-4359(03)00007-1

Assael, H. (2004). Consumer behavior: a strategic approach. Boston, MA: Houghton Mifflin.

Babin, B. \& Harris, E.G. (2016). Consumer behaviour. Mason, OH: South-Western Cengage Learning

Babin, B. J., Darden, W. R., \& Griffin, M. (1994). Work and/or Fun: Measuring Hedonic and Utilitarian Shopping Value. The Journal of Consumer Research, 20(4), 644-656. https://doi.org/10.1086/209376

Bagozzi, R.P., 1975. Marketing as exchange. Journal of Marketing, 39(4), 32-39. https://doi.org/10.1177/002224297503900405

Batra, R., \& Ahtola, O. T. (1991). Measuring the hedonic and utilitarian sources of consumer attitudes. Marketing Letters, 2(2), 159-170.

https://doi.org/10.1007/BF00436035

Beckstead, J.W. (2013). On measurements and their quality: Paper 1: Reliability-history, issues and procedures. International journal of nursing studies, 50(7), 968-973. https://doi.org/10.1016/j.ijnurstu.2013.04.005

Blunch, N.J. 2008. Introduction to structural equation modelling using SPSS and Amos. London: SAGE. https://doi.org/10.4135/9781446249345

Burke, R.R., 1997. Do you see what I see? The future of virtual shopping. Journal of the Academy of Marketing Science 25(4), 352-361. https://doi.org/10.1177/0092070397254007

Childers, T. L., Carr, C. L., Peck, J., \& Carson, S. (2002). Hedonic and utilitarian motivations for online retail shopping behavior. Journal of Retailing, 77(4), 511-535. https://doi.org/10.1016/S0022-4359(01)00056-2

Chiu, C. M., Wang, E. T., Fang, Y. H., \& Huang, H. Y. (2014). Understanding customers' repeat purchase intentions in B2C e-commerce: The roles of utilitarian value, hedonic value and perceived risk. Information System Journal, 24(1), 85-114. https://doi.org/10.1111/j.1365-2575.2012.00407.x

Chiu, J. S., \& Ting, C. C. (2011). Will you spend more money and time on Internet shopping when the product and situation are right? Computers in Human Behavior, 27(1), 203-208. https://doi.org/10.1016/j.chb.2010.07.037
Clark, L.A. \& Watson, D. (1995). Construct validity: basic issues in objective scale development. Psychological assessment, 7(3), 309-319. https://doi.org/10.1037/1040-3590.7.3.309

Davis, F.D.; Bagozzi, R.P. \& Warshaw, P.R. (1989). User acceptance of computer technology: a comparison of two theoretical models. Management Science, 35(8), 982-1003. https://doi.org/10.1287/mnsc.35.8.982

Delafrooz, N., Paim, L. H., Haron, S. A., Sidin, A. \& Khatibi (2009). Factors affecting students' attitude toward online Shopping African Journal of Business Management, 3(5), 200-209.

Evans, M., Jamal, A. \& Foxall, G. (2009). Consumer behaviour. 2nd ed. Chichester: Wiley.

Fischer, E., \& Arnold, S. J. (1990). More than a labor of love: Gender roles and Christmas shopping. Journal of Consumer Research, 17 (December), 333-345. https://doi.org/10.1086/208561

George, J. F. (2004). The theory of planned behavior and internet purchasing. Internet Research, 14(3), 198-212. https://doi.org/10.1108/10662240410542634

Guido, G. (2006). Shopping motives, big five factors, and the hedonic/utilitarian shopping value: an integration and factorial study. Innovative Marketing, 2(2), 57-67.

Hair, J.F.; Black, W.C.; Babin, B.J. \& Anderson, R.E. (2010). Multivariate data analysis: a global perspective. 7th ed. New Jersey: Pearson Education.

Hirschman, E.C., Holbrook, M.B., 1982. Hedonic consumption: emerging concepts, methods and propositions. Journal of Marketing 46 (2), 92-101. https://doi.org/10.1177/002224298204600314

Hoyer, W.D., MacInnis D.J. \& Pieters, R. 2013. Consumer behavior. 6th ed. Mason, $\mathrm{OH}$ : South-Western Cengage Learning.

Kim, H.S. (2006). Using hedonic and utilitarian shopping motivations to profile inner city consumers. Journal of Shopping Center Research, 13(1), 57-79.

Kim, Y. K. (2002). Consumer value: An application to mall and Internet shopping. International Journal of Retail \& Distribution Management, 30(12), 595-602. https://doi.org/10.1108/09590550210453075

Malhotra, N. K. (2010). Marketing research: an applied orientation. 6th ed. Upper New Jersey: Pearson Education Prentice Hall.

Malhotra, N.K. (2010). Marketing research: an applied orientation. $6^{\text {th }}$ ed. Upper New Jersey: Pearson Education Prentice Hall.

Moon, M.A., Khalid, M.I., Awan, H.M., Attiq, S., Rasool, H. \& Kiran, M. (2017). Consumer's website's utilitarian and hedonic attributes and online purchasing intentions: A cognitiveaffective attitude approach. Spanish Journal of Marketing, $21,73-88$ https://doi.org/10.1016/j.sjme.2017.07.001

Nejati, M. \& Parakhodi, M.P. (2013). The effect of hedonic and utilitarian values on satisfaction and behavioural intentions for dining in fast-casual restaurants in Iran. British Food Journal, 115(11), 1583-1596. https://doi.org/10.1108/BFJ-10-2011-0257

Pallant, J. (2013). A step by step guide to data analysis using IBM SPSS: survival manual. 5th ed. New York: McGraw-Hill.

Parsons, A.G., (2002). Non-functional motives for online shoppers: why we click. The Journal of Consumer Marketing 19(5), 380-392. https://doi.org/10.1108/07363760210437614

Redda, E.H. (2018). Positive and negative antecedents of consumer attitude towards online shopping. Journal of Economics and Behavioural Studies, 10(6):222-228. https://doi.org/10.22610/jebs.v10i6(J).2612

Redda, E.H. (2019). Attitudes towards online shopping: application of the theory of planned behaviour. Acta Universitatis Danubius, 15(2), pp. 148-159. 
Rogers, E. (1995). Diffusion of Innovations. Free Press: New York.

Rosáriol, A.M.F. \& Cruz, R. (2019). Determinants of Innovation in Digital Marketing. Journal of Reviews on Global Economics, 8, 1722-1731. https://doi.org/10.6000/1929-7092.2019.08.154

Schumacker, R.E. \& Lomax, R.G. (2010). A beginner's guide to structural equation modelling. 3rd ed. Mahwah, NJ: Lawrence Erlbaum.

Stroev, P. V., Firsov, D. V., \& Reshetnikov, S. B. (2019). Digital Economy in the Context of Phylogenesis of Innovation and Market Development. Journal of Reviews on Global Economics, 8, 417-423. https://doi.org/10.6000/1929-7092.2019.08.35

Thempson, S. (2019). What is a marketing exchange? Retrieved from: https://smallbusiness.chron.com/marketing-exchange61868.html [Accessed: 27 August 2019]

To, P.L., Liao, C. and Lin, T.H. (2007). Shopping motivations on Internet: A study based on utilitarian and hedonic value. Technovation, 27(12), 774-787. https://doi.org/10.1016/j.technovation.2007.01.001
Venkatesh, V. \& Davis, F.D. (2000). A Theoretical Extension of the Technology Acceptance Model: Four Longitudinal Field Studies. Management science, 46(2), 186-204. https://doi.org/10.1287/mnsc.46.2.186.11926

Wilson, A., Zeithaml, V., Bitner, M.J. and Gremler, D. (2016). Services marketing: Integrating customer focus across the firm. McGraw-Hill Education: New York.

Wolfinbarger, M., Gilly, M. (2001). Shopping online for freedom, control and fun. California Management Review 43(2), 34-55. https://doi.org/10.2307/41166074

Zeithaml, V.A. (1988). Customer perceptions of price, quality, and value: a measure-end model and synthesis of evidence. Journal of Marketing, (5), 2-22. https://doi.org/10.1177/002224298805200302

Zeithaml, V.A. (20120. Review of marketing 1990. Marketing Classics Press.

\section{DOI: https://doi.org/10.6000/1929-7092.2020.09.32}

\section{(c) 2020 E.H. Redda; Licensee Lifescience Global.}

This is an open access article licensed under the terms of the Creative Commons Attribution Non-Commercial License (http://creativecommons.org/licenses/by-nc/3.0/) which permits unrestricted, non-commercial use, distribution and reproduction in any medium, provided the work is properly cited. 